\title{
APPLICATION OF FAT REPLACERS AND THEIR EFFECT ON QUALITY OF COMMINUTED MEAT PRODUCTS WITH LOW LIPID CONTENT: A REVIEW
}

\author{
É. VARga-Visi* and B. ToXanbayeVA \\ Department of Food Development and Bioanalytics, Institute of Food and Agricultural Product Qualification, \\ Faculty of Agricultural and Environmental Sciences, Kaposvár University, H-7400 Kaposvár, Guba S. u. 40. \\ Hungary
}

(Received: 8 May 2015; accepted: 30 August 2015)

\begin{abstract}
In the research area of healthier meat products a possible trend is to replace high energy density fat in formulations with substances providing less energy than fat. The aim of the producers is to obtain a product having maximum yield with similar or same organoleptic properties and structure like well-known full-fat analogues. Properties of high fat products can be restored with the use of different fat substitutes, non-meat protein, and/or hydrocolloids or starch, owing to their stabilization abilities, fat coating, and water binding, respectively. The review is aimed to summarize the effect of different fat substitutes on the processing quality, textural characteristics, and sensory properties of comminuted meat products with low lipid content.

Keywords: fat replacer, comminuted meat product, cooking loss, texture profile analysis, organoleptic properties
\end{abstract}

A contradictory situation of our world is that while malnutrition still exists, significant part of the population in the countries of the industrialized world suffers from diseases that can be regarded as a consequence of overnutrition and physically inactive lifestyle. In the research area of developing healthier meat products the next main trends are standing out: development of low fat or/and low salt meat product, processing of meat products enriched with natural antioxidants, and fermented meat products that can function as probiotics (HygreEva et al., 2014). Reduction of energy density of the ingested food can decrease the risk of overweight or obesity. The fat content of meat products can be partially or totally replaced with low energy density ingredients, but this manipulation can lead to adverse effects regarding quality and therefore can be a great challenge for meat processors.

\section{Non-lipid fat replacers used for inclusion in meat products}

In an ideal case a fat substitute provides much less calories than fat, but the resulting product possesses very similar textural, technological, and organoleptic properties to commercial high fat product (KEETON, 1994). Animal fat can be replaced with carbohydrate-, protein-, or lipid based substitutes. Most applied carbohydrates are dietary fibres and modified or resistant starches. Proteins can be originated from milk, eggs, or vegetables (SchmiELE et al., 2015). Lipid based fat replacers, applied for the improvement of fatty acid composition without

\footnotetext{
* To whom correspondence should be addressed. Phone:+36-82-505-800/2307; fax: +36-82-321-749; e-mail: vargane.eva@ke.hu
} 
reduction of energy content, are not the issue of this review. The scope of this study is to summarize the technological, textural, and organoleptic effects of most often used fat replacers in low fat products in which the principal aim is to reduce energy content.

Pectin proved to be suitable for production of low fat and low salt frankfurters (PAPPA et al., 2000). Carrageenan and sodium citrate applied in low fat and low salt sausages decreased frying loss, increased firmness, juiciness, saltiness, and flavour intensity (RUUSUNEN et al., 2003). Inulin can be applied in the production of low fat sausages with acceptable quality (KeENAN et al., 2014). Fibre-rich by-products can also be utilized in the production of low fat meat products. Beside the nutritional advantages of lowering the energy density further and providing some dietary fibre, plant fibres can also improve the textural characteristics and cooking yield of low fat products, including bolognas (HYGREEVA et al., 2014), moreover the oxidative stability can also be improved owing to bioactive compounds like polyphenols in citrus fibre (ELLEUCH et al., 2011). In case of bologna sausage, the addition of citrus fibre was reported and prolonged shelf life and oxidative stability was assessed (FERNÁNDEZ-Ginés et al., 2003).

Soya proteins were successfully used to reduce the fat content of beef patties and pork sausages (DECKER et al., 1986). Soya protein together with potato flour decreased the cooking loss and a firm sausage was processed (Skrede, 1989; YANG et al., 1995). Dairy proteins, especially whey protein concentrates (WPCs) can be applied, because dairy proteins can act as water and fat binders (Comer et al., 1986; EllekJaer et al., 1996; KeEton, 1997). Nevertheless, in comminuted meat products, addition of milk protein as a dry ingredient was reported to cause an adverse effect on the texture (COMER \& ALLAN-WoJTAS, 1988; BAARDSETH et al., 1992). Pork sausages prepared with preformed gel of WPC and carrageenan completed with tapioca starch was reported to have very similar functional and organoleptic characteristic than full-fat controls (LyONS et al., 1999).

\section{The effect of fat replacers on processing properties}

Cooking loss depends on the ability of the gel matrix to immobilize fat and water in finely comminuted meat products. The addition of starch resulted the same tendency as the decreasing of fat/lean ratio, improving the water holding capacity of the emulsion and increasing the gel yield and strength (HuGHES et al., 1998). The more starch was added, the less cooking loss was detected (BAÑón et al., 2008), owing to the enhanced stability gel formation of starch under heat treatment of comminuted pork products. Modified and native starch can be applied to enhance gel stability and yield in low fat products if the degree of heat treatment is adequate for gel formation. Pre-prepared starch gels can be applied if conditions during processing would be inadequate for gel forming.

The effect of plant fibres on technological properties is not completely clarified. The inclusion of a fibre rich additive (potato pulp) did not cause an additional decrease in water and fat loss (BENGTSSON et al., 2011b), while the addition of pea fibre exerted the same effect on cooking yield as pea flour or pea starch (PIETRASIK \& JANZ, 2010). Inclusion of inulin decreased the cooking loss related to full fat product (KEENAN et al., 2014).

Protein based fat replacers like whey protein concentrate were reported to improve the solubility, viscosity, and water binding capacity of low fat meat products (MALLIKA et al., 2009). However, in a mixed gel system the contribution of whey protein concentrate was the 
smallest to the gel strength, carrageenan showed the greatest effect followed by potato starch (El-Garawany \& Abd El Salam, 2005).

\section{Instrumental measurement of texture parameters}

Evaluation of textural characteristics of bologna sausages is usually carried out using texture profile analysis (TPA). In the case of bolognas hardness, springiness, fracturability, cohesiveness, chewiness, and gumminess of low fat products were measured and compared to that of control (BAÑón et al., 2008; PietrasiK \& JANZ, 2010; ChoE et al., 2013; MARChetTi et al., 2014). Chewiness and gumminess cannot be published parallel, since chewiness refers to a solid food, while gumminess is applied for semisolid foods (BourNe, 2002). However, in some cases both terms were reported simultaneously (BAÑón et al., 2008; CHOE et al., 2013), while other authors determined only chewiness (PIETRASIK \& JANZ, 2010; MARChetTI et al., 2014). Some of these texture parameters like hardness have been reported to have significant correlation with sensory ratings (BOURNE, 2002).

\section{The effect of fat replacers on textural properties}

The main concern for quality parameters regarding emulsified meat products with low fat content is maybe not technological, like yield, but rather the consumers' concern about unacceptable texture and taste. Gel stability may not be a problem when fat content is diminished without addition of an excess amount of water, because meat proteins can form a stronger gel with less fat, but in this case the product can be firmer, drier, and more rubbery than the traditional control (KeETon, 1994). A possible reason for the too tough consistence of the formed gel is that there are less fat globules present inside the cavity of meat protein network to soften it.

Fat is often provided from sources that have other structural elements. The presence of skin from swine or poultry increases the firmness of the product, as collagen present in the connective tissue is converted to gelatine (CHOE et al., 2013). CHOE and co-workers (2013) included pig skin together with wheat fibre to replace fat in frankfurter-type sausages. Inclusion of this mixture instead of back fat enhanced the instrumentally measured hardness of the product, related to high fat control. This can be attributed to both gelatine gel formation originated from pig skin collagen and the reduced fat/lean ratio. Springiness was reduced with the use of this fat substitute, while cohesiveness and chewiness increased (СHов et al., 2013), that is the structure became less elastic and required more energy to disintegrate.

Dietary fibres have been suggested to form networks in food products (BENGTSSON et al., 2011a; BengtSSON \& ToRnBerg, 2011). Fibre networks may enhance the stability of gels via holding the water within pores, if there is no significant interaction between meat protein and fibre network (BENGTSSON et al., 2011b). In case of significant interaction between meat protein and fibre, the latter may hamper the gel formation (PAPPA et al., 2000). Interaction among carrageenan, starch and whey protein concentrate was reported to be minimal (LYONS et al., 1999), moreover the inclusion of inulin proportionally increased the hardness of low fat sausage (KEENAN et al., 2014).

Fat replacers are used to contribute to the fat and water holding capacity keeping the remaining fat and water in emulsion, but parallel to this, their use can lead to disadvantageous 
changes in the consistency of the product. When fat is partially or totally replaced with gel forming materials, the structure could be more solid than that of the traditional product. When part of the fat is replaced with water, the consistency could be too soft and technological parameters like cooking loss may also deteriorate in cases when the naturally present emulsifier (meat protein, mainly myosin) is unable to keep the excess water in emulsion. The solution would be to achieve fat reduction in such a way that fat is substituted with replacer material(s) and water, in order to provide enough binding material for the water present in excess amount without formation of a too rigid structure. Partial substitution of fat with pea fibre and water resulted in the same instrumental texture profile regarding hardness, springiness, fracturability, and cohesiveness as that of high fat control (PIETRASIK \& JANZ, 2010). Most often some TPA variables do not differ from control, some of them do, and the interpretation of the results is difficult, because the effect of a particular ingredient on textural properties is dose-dependent, therefore it cannot be generalized, moreover fat replacers are present in a complex system. Another approach is to investigate the interaction between process variables (formulation) and TPA responses with response surface methodology (RSM) that is a powerful mathematical and statistical technique in order to find the formulation that results the most similar product to the traditional one. Using the results of RSM, the level of milk protein and carrageenan addition was optimized in order to manufacture low fat product with the same hardness and springiness as the commercial product (MARCHETTI et al., 2014).

\section{The effect of fat replacers on sensory properties}

Based on the results of panel tests, one may draw the conclusion that producing low fat sausages with very similar organoleptic properties to commercial products can be achieved. Inclusion of pig skin and wheat fibre mixture instead of back fat did not change the colour, tenderness, juiciness, and flavour of the product (CHOE et al., 2013). Assessors did not find significant differences in firmness, moistness, flavour, and overall scores between low fat products with starch or pea fibre addition and high fat control (PIETRASIK \& JANZ, 2010). Carrageenan with pectin gel (CANDOGAN \& KOLSARICI, 2003) or with whey protein and tapioca starch (LyONs et al., 1999) can be successfully used without altering the sensory attributes of low fat pork sausages. However, control samples used for panel tests are not always like commercial (traditional) meat products. Low fat sausage prepared with starch instead of fat was used as control and compared to sausages with an extra addition of potato pulp without any comparison with traditional high-fat products (BENGTSSON et al., 2011b).

The colour of meat products in case of a constant meat protein ratio depends on the addition of fat, water, and other ingredients. In cured meat products in case of lower fat content the colour becomes darker and redder. Addition of flour and starch was reported to exert a minimal effect on colour both for instrumental colour parameters and customer acceptance investigations (PIETRASIK \& JANZ, 2010).

In the case of researches when both TPA analysis and panel tests were applied to evaluate the quality of low fat products, parameters of instrumental texture measurements usually do not have connection points with that of sensory evaluation. Hardness is an exception, correlation between sensory (firmness) and instrumental (hardness) detection was described previously (Bourne, 2002; KEENAN et al., 2014). Hardness of low fat sausages with starch or pea fibre addition did not differ significantly from that of high fat (control) product. In the 
same experiment, assessors did not find significant differences in firmness between products with starch or fibre addition and high fat control either (PIETRASIK \& JANZ, 2010), that is, correlation between sensory and an instrumental property was detected. Consumers considered the best texture with medium hardness for sausages (ORDÓÑEZ et al., 2001). Evaluating the other TPA parameters the question arose, which interval of TPA values is valid for a product that was assessed as having good textural properties by panellists. Establishment and introduction of well-described analogues of TPA parameters in panel test assays may help to eliminate this incompletion.

\section{Conclusions}

The effect of fat replacers on processing properties and textural parameters of comminuted meat products is dose dependent, and the possible interaction between ingredients used as fat replacer may exert also an effect on the resulting meat emulsion and therefore gel formation during cooking. Cooking loss decreases if the ratio of fat is decreased related to lean meat. When fat is partially replaced, less meat protein is required to keep the remaining lipids in emulsion, therefore the yield does not decrease unless a surplus water in added to the batter. When fat replacers are used, the greater concern is maybe not the deterioration of technological properties, but its adverse effect on textural properties. Replacement of fat with gel forming agents can lead to a firmer, dry, and rubbery product, while substitution of fat with water on equal weight basis could result in an unacceptable soft texture, therefore formulations should be set to balance between these two effects and the net result should be similar to the full-fat control. The evaluation of TPA parameters using several levels of addition of fat replacer mixes requires statistical techniques like RSM in order to establish the formulation that mostly resembles to traditional products. Correlation between consumers' acceptance and measured parameters may be established with coherent evaluation of instrumental and organoleptic data.

Toxanbayeva Botagoz PhD student is granted by the Balassi Institute (Stipendium Hungaricum Scholarship Program, K 3203).

\section{References}

Bafrdseth, P., Naes, T., Mielnik, J., Skrede, G., Holland, S. \& Eide, O. (1992): Dairy ingredients effects on sausage sensory properties studied by principle component analysis. J. Food Sci., 57, 822-828.

Baňón, S., Díaz, P., Nieto, G., Castillo, M. \& Álvarez, D. (2008): Modelling the yield and texture of comminuted pork products using color and temperature. Effect of fat/lean ratio and starch. Meat Sci., 8, 649-655.

Bengtsson, H., Hall, C. \& Tornberg, E. (2011a): Effects of physicochemical properties on the sensory perception of the texture of homogenised fruit and vegetable suspensions. J. Texture Stud., 42, 291-299.

Bengtsson, H., Montelius, C. \& Tornber, E. (2011b): Heat-treated and homogenised potato pulp suspensions as additives in low-fat sausages. Meat Sci., 88, 75-81.

Bengtsson, H. \& Tornberg, E. (2011): Physicochemical characterisation of fruit and vegetable fibre suspensions I: Effect of homogenization. J. Texture Stud., 42, 268-280.

Bourne, M.C. (2002): Food texture and viscosity: concept and measurement. Academic Press, London, UK, pp. $182-186$.

Candogan, K. \& Kolsarici, N. (2003): Storage stability of low-fat beef frankfurters formulated with carrageenan or carrageenan with pectin. Meat Sci., 64, 207-214. 
Сное, J.H., Kiм, H.Y., LeE, J.M., KIM, Y.J. \& Kiм C.J. (2013): Quality of frankfurter-type sausages with added pig skin and wheat fiber mixture as fat replacers. Meat Sci., 93, 849-854.

Comer, F.W. \& Allan-Wojtas, P. (1988): Functional and microstructural effects of fillers in comminuted meat products. Food Microstruct., 7, 25-46.

Comer, F.W., Chew, N., Lovelock, L. \& Allan-Wojtas, P. (1986): Comminuted meat products: functional and microstructural effects of fillers and meat ingredients. Can. Inst. F. Sci. Tec. J., 19, 68-74.

DeCKer, C.D., Conley, C.C. \& Richert, S.H. (1986): Use of isolated soya protein in the development of frankfurters with reduced levels of fat, calories and cholesterol. European Meeting of Meat Research Workers, 7, 1-4.

Elleuch, M., Bedigian, D., Roiseux, O., Besbes, S., Blecker, C. \& Attia, H. (2011): Dietary fibre and fibre-rich by-products of food processing: Characterisation, technological functionality and commercial applications: A review. Food Chem., 124, 411-421.

El-Garawany, G.A. \& Abd El Salam. M.H. (2005): Preparation and rheological properties of a dairy dessert based on whey protein/potato starch. Food Chem., 91, 261-267.

Ellekjaer, M.R., Naes, T. \& BaArdseth, P. (1996): Milk proteins affect yield and sensory quality of cooked sausages. J. Food Sci., 61, 660-666.

Fernández-Ginés, J.M., Fernández-López, J., Sayas-BarberÁ, E., Sendra, E. \& Pérez-Alvarez, J.A. (2003): Effect of storage conditions on quality characteristics of bologna sausages made with citrus fibre. J. Food Sci., 68, $710-715$.

Hughes, E., Mullen, A.M. \& Troy, D.J. (1998): Effects of fat level, tapioca starch and whey protein on frankfurters formulated with 5\% and 12\% fat. Meat Sci., 48, 169-180.

Hygreeva D., Pandey, M.C. \& Radhakrishna, K. (2014): Potential applications of plant based derivatives as fat replacers, antioxidants and antimicrobials in fresh and processed meat products. Meat Sci., 98, 47-57.

KeEnan, D.F., Resconi, V.C., Kerry, J.P. \& Hamill, R.M. (2014): Modelling the influence of inulin as a fat substitute in comminuted meat products on their physico-chemical characteristics and eating quality using a mixture design approach. Meat Sci., 96, 1384-1394.

KeEton, J.T. (1994): Low-fat meat products - technological problems with processing. Meat Sci., 36, $261-276$.

KeEton, J.T. (1997): Non-meat ingredients for low/non fat processed meats. Reciprocal Conference Proceedings, 49, 23-31.

Lyons, P.H., Kerry, J.F., Morrissey, P.A. \& Buckley, D.J. (1999): The influence of added whey protein/carrageenan gels and tapioca starch on the textural properties of low fat pork sausages. Meat Sci., 51, 43-52.

Mallika, E.N., Prabhakar, K. \& Reddy, P.M. (2009): Low fat meat products - an overview. Veterinary World, 9 , 364-366.

Marchetti, L., Andrés, S.C. \& Califano, A.N. (2014): Low-fat meat sausages with fish oil: Optimization of milk proteins and carrageenan contents using response surface methodology. Meat Sci., 96, 1297-1303.

OrdóÑEz, M., Rovira, J. \& JAIME, I. (2001): The relationship between the composition and texture of conventional and low-fat frankfurters. Int. J. Food Sci. Tech., 36, 749-758.

PapPa, I.C., Bloukas, J.G. \& Arvanitoyannis, I.S. (2000): Optimization of salt, olive oil and pectin level for low-fat frankfurters produced by replacing pork back fat with olive oil. Meat Sci., 56, 81-88.

PietrasiK, Z. \& JANZ, J.A.M. (2010): Utilization of pea flour, starch-rich and fiber-rich fractions in low fat bologna. Food Res. Int., 43, 602-608.

Ruusunen, M., VainionpäÄ, J., Puolanne, E., Lyly, M., LÄhteenmäki, L., Niemistö, M. \& Ahvenainen, R. (2003): Effect of sodium citrate, carboxymethyl cellulose and carrageenan levels on quality characteristics of low-salt and low-fat bologna type sausages. Meat Sci., 64, 371-381.

Schmiele, M., Mascarenhas, M.C.C.N., da Silva Barretto, A.C. \& Pollonio, M.A.R. (2015): Dietary fiber as fat substitute in emulsified and cooked meat model system. LWT - Food Sci. Technol., 61, 105-111.

Skrede, G. (1989): Comparison of various types of starch when used in meat sausages. Meat Sci., 25, 21-36.

YANG, A., Trout, G.R. \& Shay, B.J. (1995): Evaluation of carrageenan, isolated soy protein and a modified starch in low-fat frankfurters. Proceedings $41^{\text {st }}$ International Congress of Meat Science and Technology. San Antonio, Texas, USA. pp. 435-436. 